\title{
Long-term trends for nitrate and sulfate ions in snowcover on Hokkaido, northern Japan
}

\author{
Takashi YAMAGUCHI ${ }^{\mathrm{a}, \dagger}$ and Izumi NOGUCHI ${ }^{\mathrm{a}}$ \\ $\left(\begin{array}{c}\text { a Institute of Environmental Sciences, Hokkaido Research Organization, Kita19-jo Nishi12-chome, Kita-Ku, Sapporo, Hokkaido, } \\ \text { 060-0819, Japan }\end{array}\right)$
}

\begin{abstract}
On the island of Hokkaido in northern Japan, a survey of air pollutants in snowpack has been carried out every four years from 1988 to 2012. In this report Hokkaido was divided into four areas, and we determined the concentration and deposition of non-sea salt (nss) sulfate, ammonium and nitrate ions in each. Transported air pollution was found to have accumulated in the snowcover, especially on the Sea of Japan side (JS). The amount of nss-sulfate decreased continuously after 1988, but nitrate increased after 2000, especially in JS, from $3.7 \mathrm{meq} \mathrm{m}^{-2}$ (2000) to $5.3 \mathrm{meq} \mathrm{m}^{-2}$ (2012). Nitrogen deposition (nitrogen in ammonium and nitrate) was estimated at 8.9 meq m${ }^{-2}\left(1.2 \mathrm{~kg} \mathrm{~N} \mathrm{ha}^{-1}\right)$ in JS in 2012 . The nitrate/nss-sulfate concentration ratio shows a clear increasing trend. Previous studies have found that sulfur emission in China decreased after 2006. The present result appears to reflect the change in winter emissions in northern/northeastern China.
\end{abstract}

Key words: East Asia, Long range transported air pollution, Nitrogen deposition, $\mathrm{NO}_{3}{ }^{-}{ }^{-}{ }^{-} s_{-}-\mathrm{SO}_{4}{ }^{2-}$ ratio, Snowcover.

\section{Introduction}

Nitrate $\left(\mathrm{NO}_{3}{ }^{-}\right)$and non-sea salt sulfate $\left(\mathrm{nss}-\mathrm{SO}_{4}{ }^{2-}\right)$, derived respectively from nitrogen oxides $\left(\mathrm{NO}_{\mathrm{x}}\right)$ and sulfur oxides $\left(\mathrm{SO}_{2}\right)$ are the major components of acid deposition. They have been studied as factors contributing to a regional-scale environmental problem since the 1970s. Recent studies have found that nitrogen deposition alters and often decreases the diversity of plant communities. (Bobbink et al., 2010; Galloway et al., 2008; Stevens et $a l ., 2004,2011)$ The effect of nitrogen deposition is likely to be greater in mountainous areas because of their nutrient-poor soils and the shorter vegetation period. (Roth et al., 2013)

The long-range transportation of air pollution in East Asia is an international problem based in rapid economic growth. In Japan, the effect of transported air pollution is especially seen in winter months. China's contribution of emissions to the concentration of sulfate particles in Japan is $50-70 \%$, with a winter maximum of approximately $65-80 \%$ (Aikawa et al., 2010), and the concentration in rainwater and wet deposition of air pollutants is higher in winter. (Tomoyose et al., 2009) A chemical transport model study also found that the Chinese contribution has been increasing, from $40 \%$ in the 1980 s to $50 \%$ in the early $2000 \mathrm{~s}$; this upward trend was greater on the Sea of Japan side. (Kuribayashi et al., 2012)

The $\mathrm{NO}_{\mathrm{x}}$ emission in China has been increasing rapidly, and in the absence of pollution control, it will continue to increase in conjunction with energy consumption (e.g., Zhao et al., 2013; Xing et al., 2011). Emission of $\mathrm{SO}_{2}$ decreased after 2006. ( $\mathrm{Lu}$ et al., 2011) However, $\mathrm{NO}_{\mathrm{x}}$ emission has been increasing in the North China Plain and in Northeast China, and emissions are

Received; December 24, 2014.

Accepted; February 9, 2015.

${ }^{\dagger}$ Corresponding Author: t-yamaguchi@hro.or.jp

DOI: 10.2480/agrmet.D-14-00056 greater from October to May than from June to September. (Gu et al., 2013)

Long-term trends in air pollutant deposition in Japan have been previously studied. Calculated and observed $\mathrm{NO}_{3}{ }^{-}$deposition both show a slight increase from 1988 to 2002. (Noguchi et al., 2007) The trend in the $\mathrm{NO}_{3}{ }^{-} / \mathrm{nss}-\mathrm{SO}_{4}{ }^{2-}$ concentration ratio in precipitation from 1970 to 2011 reflects the changes in $\mathrm{NO}_{\mathrm{x}}$ and $\mathrm{SO}_{2}$ emissions in China. (Fujita, 2013) A similar study found that the increase in the $\mathrm{NO}_{3}{ }^{-} / \mathrm{nss}-\mathrm{SO}_{4}{ }^{2-}$ concentration ratio in precipitation (namely $0.57 \%$ /year during 2000-2005 and 2.58\%/year during 2006-2011) correspond to the changes in the $\mathrm{NO}_{\mathrm{x}} / \mathrm{SO}_{2}$ emissions ratio in China. (Itahashi et al., 2014) China's contribution to $\mathrm{NO}_{3}{ }^{-}$wet deposition in northern Japan was estimated to be 35 59\% (Morino et al., 2011); the contribution from the northern and northeastern regions in China to sulfur deposition in Hokkaido was significant. (Inoue et al., 2005) These authors also reported that more air pollutants are transported from China in the winter.

In Hokkaido, which is located in the northern part of Japan, the land is covered by snow in the winter, for half of each year. Air pollutants that have accumulated in the snowcover are released during the short period of snowmelt. (Johannessen and Henriksen, 1978) This release has a significant effect on the ecosystem due to episodic acidification. (Lepori et al., 2003) A previous study reports that $70 \%$ of hydrogen ions stored in Hokkaido's snowcover are released in a $20 \%$ snowmelt. (Satoh et al., 1999)

Particularly in winter, the dominant wind direction is westerly or northwesterly, so the deposition of air pollution in the snowcover is greatly affected by the Asian continent. Since 1988, the present authors have studied the spatial distribution and deposition of atmospheric pollutants in the snowcover. (Noguchi et al., 2005, 2001; Yamaguchi et al., 2009) Below, we examine long-term trends in the nitrate $\left(\mathrm{NO}_{3}{ }^{-}\right)$and non-sea salt sulfate $\left(\right.$nss- $\left.\mathrm{SO}_{4}{ }^{2-}\right)$ concentration and deposition. 


\section{Methods}

\subsection{Sampling periods and sites}

Snow sampling was conducted every four years $(1988,1992$, 1996, 2000, 2004, 2008, and 2012), mainly in February, which is the time of greatest snowcover. (Yamaguchi et al., 2009) To reduce contributions from local emission sources, the sample sites were selected in rural areas, away from main roads carrying traffic and artificial disturbances.

\subsection{Sampling method}

Snow samples were collected from all depths using a stainless steel pipe sampler (diameter 5.0 or $5.5 \mathrm{~cm}$ ) at $80 \sim 62$ sites and packed in plastic bags, which had been washed with deionized water. The number of sites varied from year to year due to traffic or weather conditions. The depth of the snowcover at the site was recorded and was used to calculate the snow volume and density. The samples were melted at room temperature and weighed. After being passed through a membrane filter (pore size: $0.2 \mu \mathrm{m}$ ), the electrical conductivity and $\mathrm{pH}$ were promptly measured using a conductivity meter and a $\mathrm{pH}$ meter. The samples were then stored in a refrigerator. The major inorganic ions, sulfate $\left(\mathrm{SO}_{4}{ }^{2-}\right)$, nitrate $\left(\mathrm{NO}_{3}{ }^{-}\right)$, chloride $\left(\mathrm{Cl}^{-}\right)$, ammonium $\left(\mathrm{NH}_{4}^{+}\right)$, calcium $\left(\mathrm{Ca}^{2+}\right)$, magnesium $\left(\mathrm{Mg}^{2+}\right)$, sodium $\left(\mathrm{Na}^{+}\right)$and potassium $\left(\mathrm{K}^{+}\right)$were measured by ion chromatography or automated colorimetry or by atomic absorption spectrography. Non-sea salt sulfate and calcium (nss- $\mathrm{SO}_{4}{ }^{2-}$ and nss-Ca ${ }^{2+}$ ) were calculated using $\mathrm{Na}^{+}$as a sea salt index, as follows:

nss- $\mathrm{SO}_{4}{ }^{2-}\left(\mathrm{mol} \mathrm{L}^{-1}\right)=\mathrm{SO}_{4}{ }^{2-}\left(\mathrm{mol} \mathrm{L}^{-1}\right)-0.06028 \times \mathrm{Na}^{+}\left(\mathrm{mol} \mathrm{L}^{-1}\right)$

\subsection{Spatial analysis}

The amount of precipitation was calculated from precipitation data taken from AMeDAS (Automated Meteorological Data Acquisition System, Japan Meteorological Agency) during the snowcover period. The snowcover period was defined as falling between the date when the seven-day moving average temperature fell below $0^{\circ} \mathrm{C}$ and the date when the seven-day moving average temperature rose above $0{ }^{\circ} \mathrm{C}$. Spatial distribution maps of the amount of accumulated precipitation were drawn using Kriging interpolation. (Oliver and Webster, 1990) The maps of ion concentrations were also interpolated using the Kriging method. The accumulated ion components deposited in the snowcover was calculated by multiplying the grid data for the amount of precipitation and the concentrations of each ion.

For regional evaluation, we divided Hokkaido into four areas (JS: Sea of Japan, OH: Sea of Okhotsk, PO: Pacific Ocean, and IL: Inland) and calculated the mean concentrations and the deposition of ions in each area, as shown in Fig. 1. Table 1 shows the areas, the mean snow depth as precipitation and the total amount of precipitation in each region. Adding the calculations for the

Table 1. Area of each region, mean snow depth and amount of snow in 2012.

\begin{tabular}{crcc}
\hline Region & Area $\left(\mathrm{km}^{2}\right)$ & Mean snow depth in 2012 $(\mathrm{mm})$ & Snow amount in 2012 $\left(\mathrm{Mm}^{3}\right)$ \\
\hline IL & 16390 & 298 & 4880 \\
JS & 18690 & 326 & 6090 \\
OH & 14100 & 177 & 2500 \\
PO & 28570 & 188 & 5370 \\
\hline Total & 78440 & 242 & 19020 \\
\hline
\end{tabular}

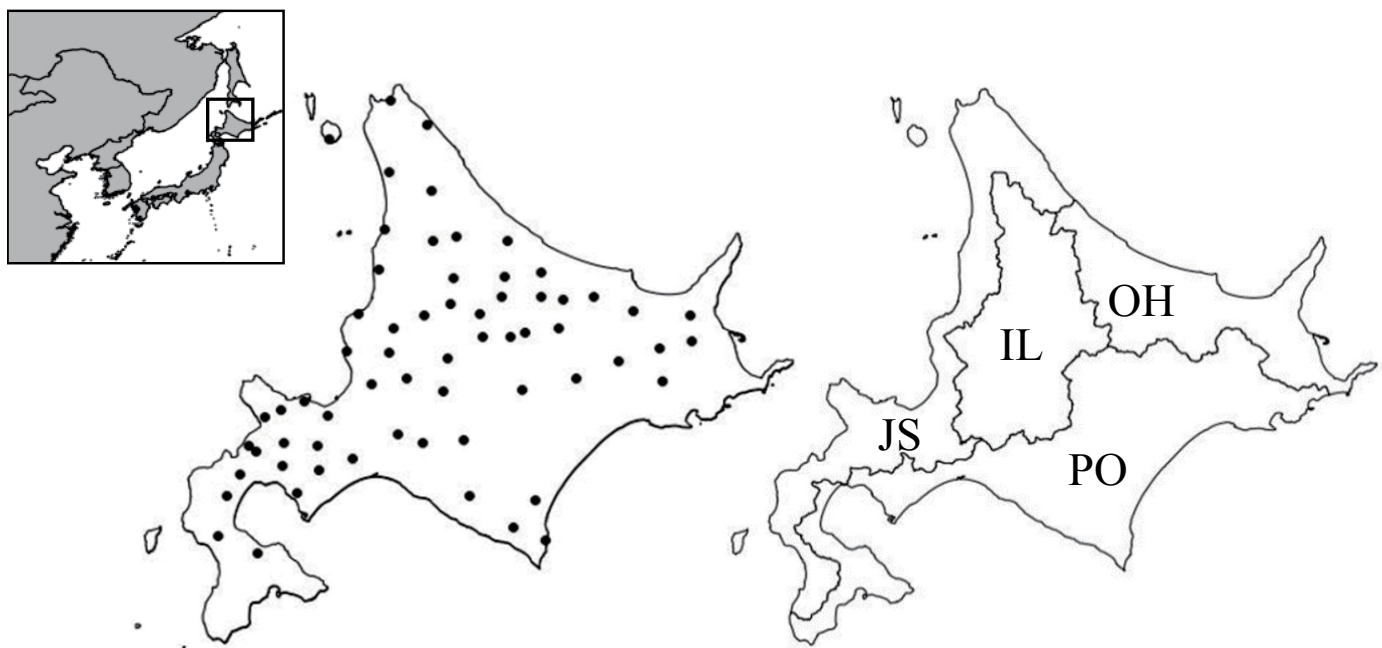

Fig. 1. Sampling sites in the 2012 survey and partition into regions. 


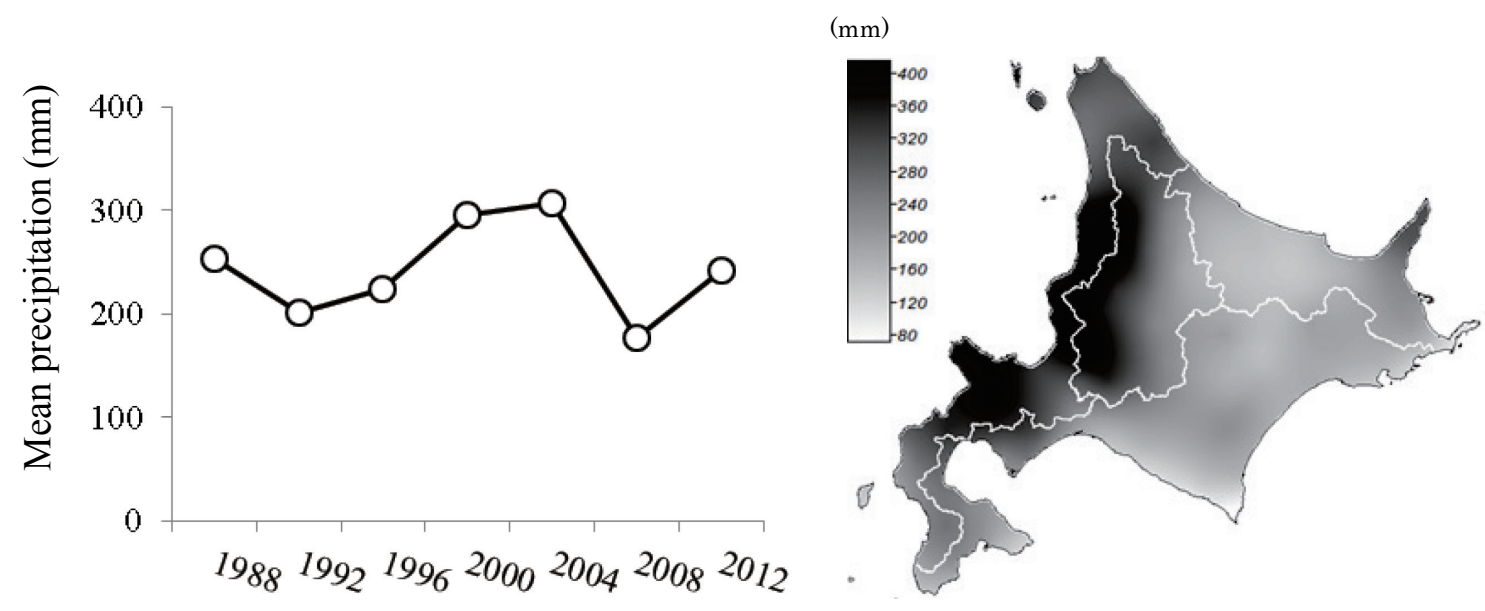

Fig. 2. Temporal trend in the amount of snow as precipitation and its spatial distribution in 2012 .

areas in Table 1 does not result in the total due to rounding.

\section{Results}

\subsection{Amount of precipitation}

Figure 2 shows the change in the amount of accumulated precipitation. The amount of precipitation was approximately 250 $\mathrm{mm}$, with a minimum of $180 \mathrm{~mm}$ occurring in 2008. In 2012 the amount of precipitation was $242 \mathrm{~mm}$. Region by region, the amount of precipitation was $177 \mathrm{~mm}$ in $\mathrm{OH}, 188 \mathrm{~mm}$ in PO, 326 $\mathrm{mm}$ in JS and $298 \mathrm{~mm}$ in IL. The amount in the JS and IL regions was usually high (Table 1, Fig. 2.) .

\subsection{Concentration and accumulated deposition of ion compo-} nents

The temporal trend of the regional mean concentration $\left(\mu \mathrm{eq} \mathrm{L}^{-1}\right)$ and the deposition $\left(\right.$ meq $\mathrm{m}^{-2}$ ) of each ion in the snowcover are shown in Table 2 and Fig. 3. As an example, Fig. 4 shows the spatial distribution of the concentration and the deposition of each ion in 2012.

\subsubsection{Concentration}

The nss- $\mathrm{SO}_{4}{ }^{2-}$ concentration was high in the JS region and the $\mathrm{NO}_{3}{ }^{-}$concentration was high in JS and IL. The $\mathrm{NH}_{4}{ }^{+}$concentration did not vary from region to region (Fig. 3, Table 2). The $\mathrm{NO}_{3}{ }^{-}$concentration held steady at about $10 \mu \mathrm{eq} \mathrm{L}{ }^{-1}$ from 1988 to 2000, and then increased, especially in IL and JS, to $12-21 \mu \mathrm{eq} \mathrm{L}^{-1}$.
The nss- $\mathrm{SO}_{4}{ }^{2-}$ concentration fell from 1988 to 2000 and rose temporarily in 2008 . The amount of precipitation affects the concentrations of atmospheric pollutants. (Barrie, 1985) The high concentration of air pollutants in 2008 is therefore believed to be due to the small amount of precipitation in that year.

\subsubsection{Deposition}

The deposition of $\mathrm{NO}_{3}{ }^{-}$was steady below 4.0 meq $\mathrm{m}^{-2}$ in IL and JS in the 1990s but has increased since 2000. In 2012, the deposition of $\mathrm{NO}_{3}^{-}$was 4.8 meq m${ }^{-2}\left(0.67 \mathrm{~kg} \mathrm{~N} \mathrm{ha}^{-1}\right)$ in IL and $5.3 \mathrm{meq} \mathrm{m}^{-2}\left(0.74 \mathrm{~kg} \mathrm{~N} \mathrm{ha}^{-1}\right)$ in JS (Table 2, Fig. 3b) .

Deposition of $\mathrm{NO}_{3}^{-}$in $\mathrm{PO}$ and $\mathrm{OH}\left(1.3 \sim 2.8 \mathrm{meq} \mathrm{m}{ }^{-2}\right)$ was about half of that in IL and JS, although they also showed an increasing trend after 2000. The fall in PO in 2008 was due to the small amount of precipitation that year. Ammonium deposition did not show any clear temporal trend. It fell until 1996, then increased, and decreased slightly in 2012. Nitrogen deposition $\left(\mathrm{NH}_{4}{ }^{+} \mathrm{N}+\mathrm{NO}_{3}{ }^{-} \mathrm{N}\right)$ in 2012 ranged from $3.0 \mathrm{meq} \mathrm{m}{ }^{-2}(\mathrm{OH}, 0.4$ $\mathrm{kg} \mathrm{N} \mathrm{ha}^{-1}$ ) to 8.9 meq m${ }^{-2}$ (JS, $1.2 \mathrm{~kg} \mathrm{~N} \mathrm{ha}^{-1}$ ); see Table 2 .

Deposition of nss- $\mathrm{SO}_{4}{ }^{2-}$ was greatest in all regions in 1988. Since then it has been falling continuously. For example, it was $9.4 \mathrm{meq} \mathrm{m}^{-2}\left(3.0 \mathrm{~kg} \mathrm{~S} \mathrm{ha}^{-1}\right)$ in JS and had fallen steadily to half that value by 2012 .

\subsection{3 $\mathrm{NO}_{3}{ }^{-} / \mathrm{nss}^{-\mathrm{SO}_{4}}{ }^{2-}$ concentration ratio}

The temporal trend in the $\mathrm{NO}_{3}{ }^{-}$nss- $\mathrm{SO}_{4}{ }^{2-}$ concentration ratio in

Table 2. Regional mean concentration $\left(\mu \mathrm{eq} \mathrm{L}^{-1}\right)$ and deposition (meq $\mathrm{m}^{-2}$ ) of each ion in snow cover from 1988 to 2012.

\begin{tabular}{|c|c|c|c|c|c|c|c|c|c|c|c|c|c|c|c|c|c|c|c|c|c|c|}
\hline & & \multicolumn{7}{|c|}{$\mathrm{NH}_{4}^{+}$} & \multicolumn{7}{|c|}{$\mathrm{NO}_{3}^{-}$} & \multicolumn{7}{|c|}{ nss- $\mathrm{SO}_{4}{ }^{2-}$} \\
\hline & & 1988 & 1992 & 1996 & 2000 & 2004 & 2008 & 2012 & 1988 & 1992 & 1996 & 2000 & 2004 & 2008 & 2012 & 1988 & 1992 & 1996 & 2000 & 2004 & 2008 & 2012 \\
\hline \multirow[t]{2}{*}{ IL } & $\left(\mu \mathrm{eq} \mathrm{L}^{-1}\right)$ & 8.8 & 12.8 & 8.2 & 9.1 & 10.5 & 14.7 & 9.7 & 10.3 & 12.2 & 9.5 & 11.1 & 13.8 & 21.7 & 16.2 & 24.0 & 23.7 & 18.9 & 14.5 & 16.1 & 20.6 & 12.7 \\
\hline & $\left(\right.$ meq m $\left.\mathrm{m}^{-2}\right)$ & 3.1 & 3.6 & 2.4 & 3.3 & 3.8 & 3.7 & 2.9 & 3.6 & 3.7 & 2.9 & 3.8 & 4.9 & 5.6 & 4.8 & 8.2 & 6.6 & 5.5 & 5.2 & 5.8 & 5.2 & 3.8 \\
\hline \multirow[t]{2}{*}{ JS } & $\left(\mu\right.$ eq $\left.L^{-1}\right)$ & 14.5 & 13.6 & 8.9 & 11.0 & 12.4 & 15.5 & 11.2 & 9.2 & 11.1 & 10.1 & 10.1 & 12.4 & 19.9 & 16.7 & 25.5 & 29.4 & 25.9 & 19.6 & 21.1 & 22.7 & 16.9 \\
\hline & $\left(\mathrm{meq} \mathrm{\textrm {m } ^ { - 2 }}\right)$ & 5.3 & 3.9 & 2.6 & 4.0 & 4.1 & 4.0 & 3.6 & 3.4 & 3.3 & 2.9 & 3.7 & 4.1 & 5.2 & 5.3 & 9.4 & 8.4 & 7.5 & 7.2 & 6.9 & 5.9 & 5.5 \\
\hline \multirow[t]{2}{*}{$\mathrm{OH}$} & $\left(\mu \mathrm{eq} \mathrm{L}^{-1}\right)$ & 12.8 & 11.4 & 6.1 & 7.9 & 7.3 & 13.4 & 8.0 & 9.0 & 7.2 & 6.6 & 5.7 & 6.5 & 14.3 & 9.0 & 27.7 & 19.9 & 16.4 & 10.6 & 12.6 & 20.3 & 11.7 \\
\hline & $\left(\mathrm{meq} \mathrm{m}^{-2}\right)$ & 2.12 & 1.58 & 1.02 & 1.81 & 2.19 & 1.86 & 1.43 & 1.51 & 1.36 & 1.33 & 1.38 & 1.97 & 2.12 & 1.56 & 4.6 & 2.8 & 2.7 & 2.4 & 3.8 & 2.8 & 2.0 \\
\hline \multirow[t]{2}{*}{ PO } & $\left(\mu \mathrm{eq} \mathrm{L}^{-1}\right)$ & 15.0 & 11.9 & 7.1 & 7.7 & 8.0 & 14.9 & 11.6 & 11.7 & 10.7 & 9.2 & 7.6 & 8.9 & 15.6 & 14.7 & 32.5 & 23.2 & 19.1 & 10.8 & 13.2 & 23.3 & 15.7 \\
\hline & $\left(\mathrm{meq} \mathrm{m}^{-2}\right)$ & 2.4 & 1.6 & 1.2 & 1.9 & 2.1 & 1.5 & 2.2 & 1.9 & 1.4 & 1.4 & 2.0 & 2.4 & 1.6 & 2.8 & 5.1 & 3.2 & 3.3 & 2.7 & 3.5 & 2.2 & 2.9 \\
\hline
\end{tabular}


(a) Mean concentration in each region $\left(\mu \mathrm{eq} \mathrm{L}^{-1}\right)$

$$
-\square \text { JS } \bullet \mathrm{IL} \quad \longleftarrow \mathrm{OH} \quad-\bullet-\mathrm{PO}
$$
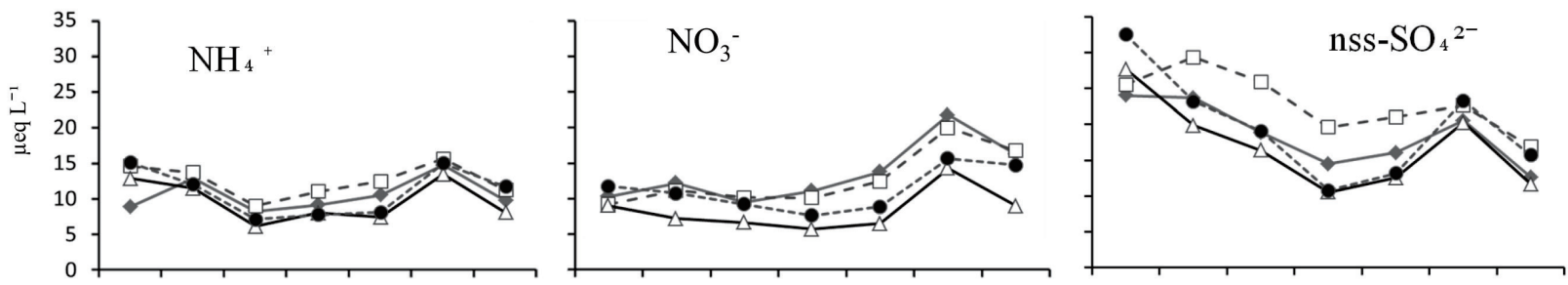

(b) Deposition in each region (meq $\mathrm{m}^{-2}$ )
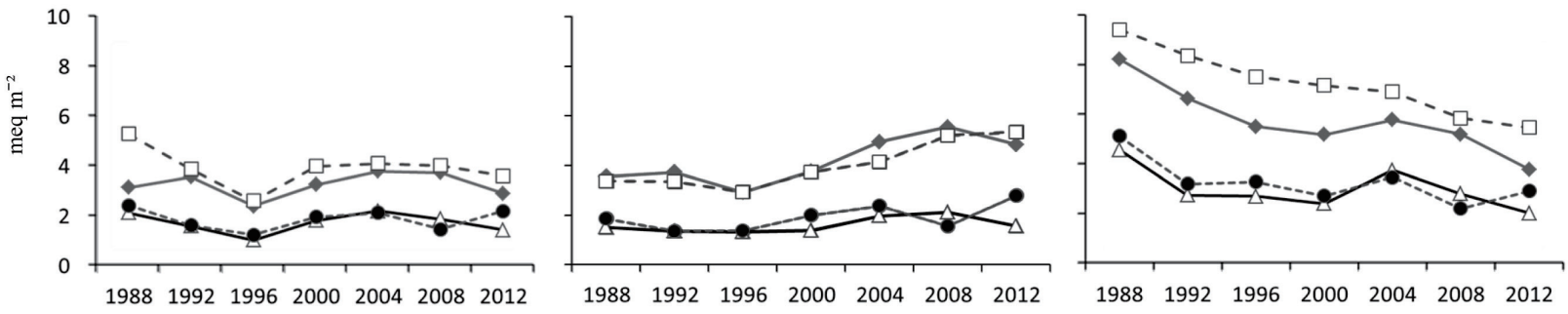

Fig. 3. (a) Mean concentration $\left(\mu \mathrm{eq} \mathrm{L}^{-1}\right)$ and (b) deposition $\left(\mathrm{meq} \mathrm{m}^{-2}\right.$ ) of each ion in snow cover at each region from 1988 to 2012.

(a) Concentration
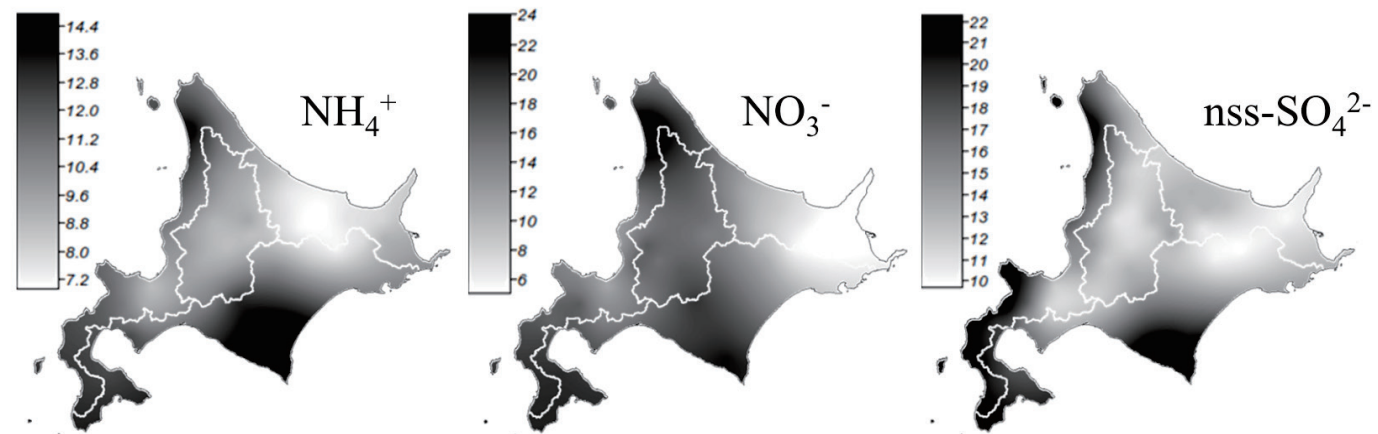

(b) Amount
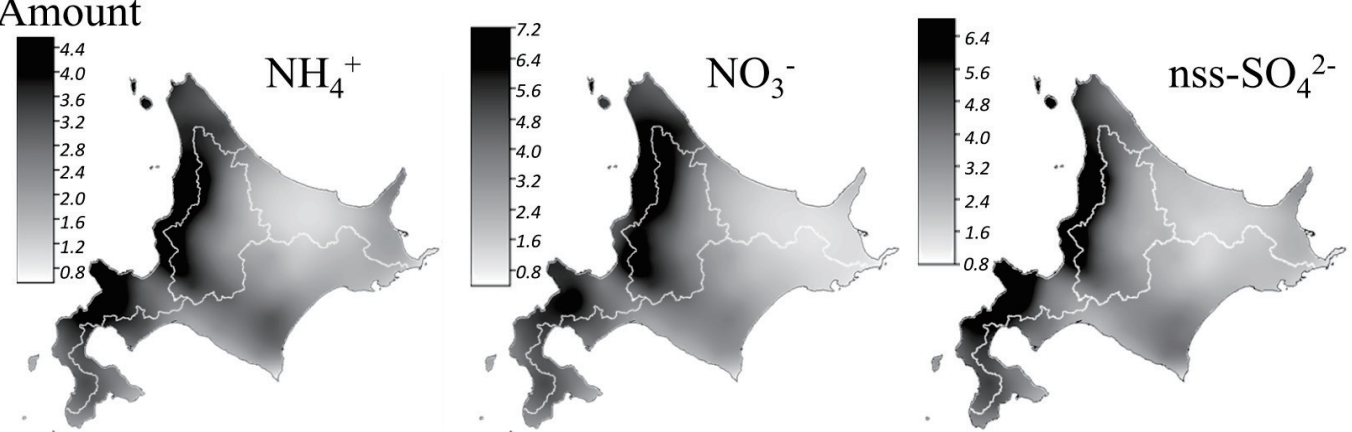

Fig. 4. Estimated spatial distribution of (a) concentrations $\left(\mu \mathrm{eq} \mathrm{L}^{-1}\right.$ ) and (b) deposition (meq m${ }^{-2}$ ) of $\mathrm{nss}^{-} \mathrm{SO}_{4}{ }^{2-}, \mathrm{NO}_{3}{ }^{-}$and $\mathrm{NH}_{4}{ }^{+}$ in snowcover in 2012 .

each region is shown in Fig. 5. After 1996 all the regions showed clear increases, which were largest in IL (1.28 in 2012). The increase was smallest in $\mathrm{OH}$, at 0.76 in 2012. The annual mean rate of increase was $4.6 \%$ in IL and $3.8 \%$ in JS. Values were $1.6 \%$ in $\mathrm{OH}$ and $1.8 \%$ in PO. In PO it rose in 2000 , to 0.75 , and the rate of increase thereafter was small.

\section{Discussion}

\subsection{Concentration and $\mathrm{NO}_{3}{ }^{-} / \mathrm{nss}_{-} \mathrm{SO}_{4}{ }^{2-}$ concentration ratio}

We observed an increase in the $\mathrm{NO}_{3}{ }^{-}$concentration and a de- crease in the nss- $\mathrm{SO}_{4}{ }^{2-}$ concentration. The $\mathrm{NO}_{3}{ }^{-} / \mathrm{nss}^{-} \mathrm{SO}_{4}{ }^{2-}$ ratio has therefore been increasing throughout the study period; the increase we found is greater than in a previous study. (1.4\%, Fujita, 2013) One previous study found that the $\mathrm{NO}_{3}{ }^{-} / \mathrm{nss}-\mathrm{SO}_{4}{ }^{2-}$ ratio in Japan increased after 2006 (Itahashi et al., 2014) in a manner consistent with the change in the $\mathrm{SO}_{2}$ emission in China (Lu et al., 2011). The differing values found for nss- $\mathrm{SO}_{4}{ }^{2-}$ change in the present study could be due to the geographical location of Hokkaido relative to China and seasonal differences. The contribution of north and northeast China to sulfur deposition in Hok- 


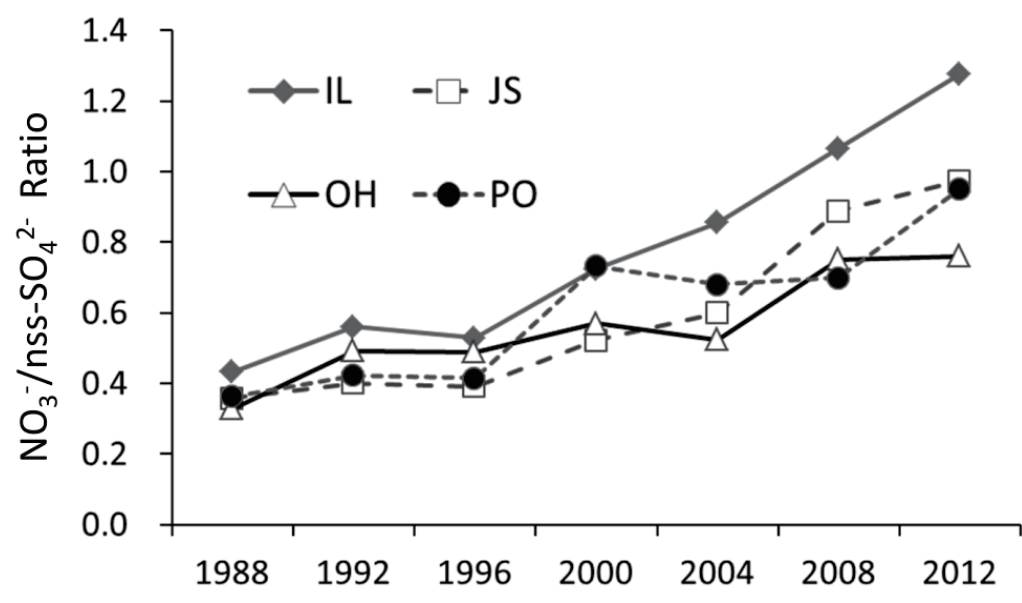

Fig. 5. Long-term trend in the $\mathrm{NO}_{3}{ }^{-} / \mathrm{nss}^{-\mathrm{SO}_{4}}{ }^{2-}$ concentration ratio in snow cover from 1988 to 2012 .

kaido was estimated to be $41 \%$; these are the areas that contribute most. (Inoue et al., 2005) The recent increasing $\mathrm{NO}_{\mathrm{x}}$ trend in northern and northeastern China in the colder seasons was also larger than in other areas in China from 2005-2010. (Gu et al., 2013) Observations in Japan also found that air pollution transported from the Asian continent was significant during winter. (Aikawa et al., 2010; Tomoyose et al., 2009; Var et al., 2000) The present study is limited to the winter period, and our results could reflect changes in $\mathrm{SO}_{2}$ and $\mathrm{NO}_{\mathrm{x}}$ emission in the northern/northeastern part of China in winter.

The $\mathrm{NO}_{3}{ }^{-} / \mathrm{nss}^{-} \mathrm{SO}_{4}{ }^{2-}$ ratio has been above $1.0 \mathrm{in} \mathrm{IL}$ and is also close to 1.0 in JS and PO. We deduce that the dominant component of acidification in winter is changing from $\mathrm{SO}_{2}$ to $\mathrm{NO}_{\mathrm{x}}$.

\subsection{Deposition}

Nitrogen deposition in 2012 was greatest in JS $\left(8.9 \mathrm{meq} \mathrm{m}^{-2}\right.$ $\left.\left(1.2 \mathrm{~kg} \mathrm{~N} \mathrm{ha}^{-1}\right)\right)$; see Table 2. The observed annual wet nitrogen deposition at Rishiri Island, located in JS, was $29 \mathrm{mmol} \mathrm{m}^{-2} \mathrm{y}^{-1}$ (4.0 kg N ha $\mathrm{y}^{-1}$ ) in 2012 (Network Center for EANET, 2013). Nitrogen deposition in the snowcover in JS was close to one third of the annual wet nitrogen deposition.

The snowmelt period in Hokkaido lasts about two months, from mid-March to mid-May. Nitrogen stored in the snowcover will be eluted during this period. Furthermore, the chemicals in the snow are concentrated in the early snowmelt water (Johannessen and Henriksen, 1978; Satoh et al., 1999; Brooks and Williams, 1999) and affect the ecosystem via episodic acidification. (Lepori et al., 2003) If there continues to be an absence of air pollution regulations in China, $\mathrm{NO}_{\mathrm{x}}$ emission will continue to increase as well. (Zhao et al., 2013; Xing et al., 2011)

The concentration of atmospheric pollution was large in the cloud/fog and rime, and deposition in correspondence with these was also significant in mountainous areas. (Igawa et al., 2002; Nagafuchi et al., 2001; Yamaguchi et al., 2015) We excluded the mountainous area from our study because of the difficulty of sampling. The deposition of atmospheric pollution might therefore be larger than that found in this study. Furthermore, sensitive plants or microorganisms in high areas are strongly influenced by the increase in nitrogen deposition (e.g. Fenn et al., 2003, Williams et al., 1996). The snowcover in the mountainous areas should be studied further.

\section{Conclusion}

Deposition of air pollutants in the snowcover was significant on the Sea of Japan side of Hokkaido island. Nitrate deposition increased after 2000, whereas nss- $\mathrm{SO}_{4}{ }^{2-}$ deposition has been decreasing throughout the study period. Nitrogen deposition on the Sea of Japan side was estimated to be $8.9 \mathrm{meq} \mathrm{m}^{-2}\left(1.2 \mathrm{~kg} \mathrm{~N} \mathrm{ha}^{-1}\right)$, corresponding to one third of the annual nitrogen wet deposition. The $\mathrm{NO}_{3}{ }^{-} / \mathrm{nss}^{-} \mathrm{SO}_{4}{ }^{2-}$ concentration ratio increased continually throughout the study period, from 1988 to 2012. A possible explanation is that the changes are due to increased regional emission in the northern and northeastern China. The increase in nitrogen deposition is believed to affect the ecosystem, especially in the mountainous areas on the Sea of Japan side of Hokkaido island.

\section{Acknowledgements}

A special thanks is to Dr. Anthony Garret of Cambridge, U.K. for his linguistic improvement of our manuscript via SCITEXT.

\section{References}

Aikawa, M., Ohara, T., Hiraki, T., Oishi, O., Tsuji, A., Yamagami, M., Murano, K. and Mukai, H., 2010: Significant geographic gradients in particulate sulfate over Japan determined from multiple-site measurements and a chemical transport model: Impacts of transboundary pollution from the Asian continent. Atmospheric Environment, 44 (3), 381-391.

Barrie, L. A., 1985: Scavenging ratios, wet deposition, and in cloud oxidation: An application to the oxides of sulphur and nitrogen. Journal of Geophysical Research: Atmospheres (19842012), 90 (D3), 5789-5799.

Bobbink, R., Hicks, K., Galloway, J., Spranger, T., Alkemade, R., Ashmore, M., Bustamante, M., Cinderby, S., Davidson, E. and Dentener, F., 2010: Global assessment of nitrogen deposition effects on terrestrial plant diversity: a synthesis. Ecological Applications, 20 (1) , 30-59.

Brooks, P. D. and Williams, M. W., 1999: Snowpack controls on nitrogen cycling and export in seasonally snow-covered catchments. Hydrological Processes, 13 (14), 2177-2190.

Fenn, M. E., Baron, J. S., Allen, E. B., Rueth, H. M., Nydick, K. R., Geiser, L., Bowman, W. D., Sickman, J. O., Meixner, T. 
and Johnson, D. W., 2003: Ecological effects of nitrogen deposition in the western United States. BioScience. 53 (4), 404-420.

Fujita, S., 2013: Long-term trends in the nitrate to non-sea-salt sulfate ratio in precipitation over the Japanese archipelag. Journal of Japan Society for Atmospheric Environment, 48 (1) , 1219. (in Japanese with English summary)

Galloway, J. N., Townsend, A. R., Erisman, J. W., Bekunda, M., Cai, Z., Freney, J. R., Martinelli, L. A., Seitzinger, S. P. and Sutton, M. A., 2008: Transformation of the nitrogen cycle: Recent trends, questions, and potential solutions. Science, 320 (5878), 889-892.

Gu, D., Wang, Y., Smeltzer, C. and Liu, Z., 2013: Reduction in NOx Emission trends over China: regional and seasonal variations. Environmental Science \& Technology, 47(22), 1291212919.

Igawa, M., Matsumura, K. and Okochi, H., 2002: High frequency and large deposition of acid fog on high elevation forest. Environmental Science \& Technology, 36 (1), 1-6.

Inoue, M., Ohara, T., Katayama, M. and Murano, K., 2005: Annual source-receptor relationships of sulfur in East Asia using a numerical simulation model RAMS/HYPACT. Earozoru Kenkyu, 20 (4) , 333-344. (in Japanese with English summary)

Itahashi, S., Uno, I., Hayami, H. and Fujita, S., 2014: Modeling investigation of controlling factors in the increasing ratio of nitrate to non-seasalt sulfate in precipitation over Japan. Atmospheric Environment, 92, 171-177.

Johannessen, M. and Henriksen, A., 1978: Chemistry of snow meltwater: changes in concentration during melting. Water Resources Research, 14 (4), 615-619.

Kuribayashi, M., Ohara, T., Morino, Y., Uno, I., Kurokawa, J. and Hara, H., 2012: Long-term trends of sulfur deposition in East Asia during 1981-2005. Atmospheric environment, 59, 461475.

Lepori, F., Barbieri, A. and Ormerod, S. J., 2003: Effects of episodic acidification on macroinvertebrate assemblages in Swiss Alpine streams. Freshwater Biology, 48 (10), 1873-1885.

Lu, Z., Zhang, Q. and Streets, D. G., 2011: Sulfur dioxide and primary carbonaceous aerosol emissions in China and India, 1996-2010. Atmospheric Chemistry and Physics, 11(18), 9839-9864.

Morino, Y., Ohara, T., Kurokawa, J., Kuribayashi, M., Uno, I. and Hara, H., 2011: Temporal variations of nitrogen wet deposition across Japan from 1989 to 2008. Journal of Geophysical Research: Atmospheres (1984-2012), 116(D6) , D06307.

Nagafuchi, O., Mukai, H. and Koga, M., 2001: Black acidic rime ice in the remote island of Yakushima, a world natural heritage area. Water, Air, and Soil Pollution, 130 (1-4), 1565-1570.

Network Center for EANET, 2013: Data Report on the Acid Deposition in the East Asian Region 2012, [online] Available at: http://www.eanet.asia/product/datarep/datarep12/datarep12.pdf.

Noguchi, I., Hayashi, K., Aikawa, M., Ohizumi, T., Minami, Y., Kitamura, M., Takahashi, A., Tanimoto, H., Matsuda, K. and Hara, H., 2007: Temporal trends of non-sea salt sulfate and nitrate in wet deposition in Japan. Water, Air, and Soil Pollution: Focus, (7), 67-75.

Noguchi, I., Katoh, T., Sakai, S., Iwata, R., Akiyama, M., Ohtsuka, H., Sakata, K., Aga, H. and Matsumoto, Y., 2001: Snowcover components in northern Japan. Water, Air, and Soil Pollution, 130 (1-4), 421-426.

Noguchi, I., Sakai, S., Iwata, R., Akiyama, M., Aga, H., Tanaka, T., Tobisawa, T., Fukazawa, T. and Tachibana, H., 2005: Distribution of snow cover components in Hokkaido.-1988, 1992,
1996, 2000 and 2004. Report of Hokkaido Institute of Environmental Sciences, 31, 65-73. (in Japanese)

Oliver, M. A. and Webster, R., 1990: Kriging: a method of interpolation for geographical information systems. International Journal of Geographical Information System, 4 (3), 313-332.

Roth, T., Kohli, L., Rihm, B. and Achermann, B., 2013: Nitrogen deposition is negatively related to species richness and species composition of vascular plants and bryophytes in Swiss mountain grassland. Agriculture, Ecosystems \& Environment, 178, 121-126.

Satoh, F., Nomura, M., Masumoto, H., Ashiya, D. and Sasa, K., 1999: Ionic elution from the acidic snowpack during spring thaw period in the northern part of Hokkaido. Research Bulletin of the Hokkaido University Forests, 56 (2) , 1-10.

Stevens, C. J., Dise, N. B., Mountford, J. O. and Gowing, D. J., 2004: Impact of nitrogen deposition on the species richness of grasslands. Science, 303 (5665), 1876-1879.

Stevens, C. J., Manning, P., Van den Berg, L. J., De Graaf, M. C., Wamelink, G. W., Boxman, A. W., Bleeker, A., Vergeer, P., Arroniz-Crespo, M. and Limpens, J., 2011: Ecosystem responses to reduced and oxidised nitrogen inputs in European terrestrial habitats. Environmental Pollution, 159 (3), 665-676.

Tomoyose, N., Noguchi, I., Ohizumi, T., Kitamura, Y., Nakagawa, F., Mizoguchi, T., Murano, K. and Mukai, H., 2009: Studies on trans-boundary air pollution in view of wet deposition data (FY2003-FY2006) monitored in the survey by Japan environmental laboratories, Journal of Japan Society for Atmospheric Environment, 44(2), 117-127. (in Japanese with English summary)

Var, F., Narita, Y. and Tanaka, S., 2000: The concentration, trend and seasonal variation of metals in the atmosphere in 16 Japanese cities shown by the results of National Air Surveillance Network (NASN) from 1974 to 1996. Atmospheric Environment, 34 (17), 2755-2770.

Williams, M. W., Baron, J. S., Caine, N., Sommerfeld, R. and Sanford Jr, R., 1996: Nitrogen saturation in the Rocky Mountains. Environmental Science \& Technology, 30 (2), 640-646.

Xing, J., Wang, S. X., Chatani, S., Zhang, C. Y., Wei, W., Hao, J. M., Klimont, Z., Cofala, J. and Amann, M., 2011: Projections of air pollutant emissions and its impacts on regional air quality in China in 2020. Atmospheric Chemistry and Physics, 11 (7), 3119-3136.

Yamaguchi, T., Katata, G., Noguchi, I., Sakai, S., Watanabe, Y., Uematsu, M. and Furutani, H., 2015: Long-term observation of fog chemistry and estimation of fog water and nitrogen input via fog water deposition at a mountainous site in Hokkaido, Japan. Atmospheric Research, 151 (1), 82-92.

Yamaguchi, T., Noguchi, I., Aga, H., Iwata, R., Ueno, Y., Akiyama, M., Otsuka, H., Sakai, S., Nagahora, S., Yamaguchi, K., Niwa, S., Ohara, H., Tanaka, T., Anezaki, K. and Hamahara, K., 2009: Long term trend of snow cover components in Hokkaido (1988-2008). Report of Hokkaido Institute of Environmental Sciences, 35, 61-68. (in Japanese)

Zhao, B., Wang, S. X., Liu, H., Xu, J. Y., Fu, K., Klimont, Z., Hao, J. M., He, K. B., Cofala, J. and Amann, M., 2013: NOx emissions in China: historical trends and future perspectives. Atmospheric Chemistry and Physics, 13 (19), 9869-9897. 